\title{
FACEBOOK AS AN INFORMATION MANAGEMENT TOOL - IN THE LIGHT OF RESEARCH CONDUCTED AMONG POLISH STUDENTS \\ MALWINA POPIOEEK

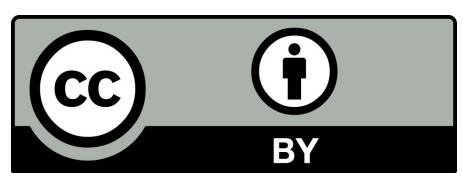

Faculty of Management and Social Communication, Jagiellonian University, ul. S. Łojasiewicza 4, Kraków, Poland

E-mail address: m.popiolek@uj.edu.pl

BOGUSŁAW NIERENBERG

Faculty of Management and Social Communication, Jagiellonian University, ul. S. Łojasiewicza 4, Kraków, Poland

E-mail address: boguslaw.nierenberg@uj.edu.pl

\begin{abstract}
The paper offers a look at the Facebook social service from the point of view of information management in an information society. The article presents a description and comparison of two sets of focus group research. The study was carried out among students in an academic center in a small city (population of 120,000), and in an academic center in a big city (population exceeding 750,000). The research was aimed at exploring issues related to using Facebook, in particular the issue of motives related to creating a profile on the service and using it in everyday life. The research has revealed three categories related to Facebook use: a need for security in the scope of access to information, a need to possess a tool facilitating management of information-communication processes, as well as a respondent's dislike for Facebook. In the final part, the paper presents conclusions, but also limitations of the described research.
\end{abstract}

Key words: Facebook, social network sites, information society, network society, social media, information management

\section{INTRODUCTION}

The point of focus of this paper is Facebook - currently (2017) the most popular social network site among Internet users. The article embarks on an exploration of issues related to the growing popularity of the service. Facebook is analysed through the prism of processes transpiring in the information society, especially in the context of managing information via new media.

The first part of the paper provides a description of issues concerning the role and significance of information in the information society. It also offers an explanation of the authors' understanding of the notion of "information 
management". The following part provides short characteristics of Facebook, as well as a review of the research focusing on this service. The main trends as well as researchers' approaches related to Facebook's role and significance in daily life of its users are presented. Next, the paper proceeds to present results of the focus group research conducted for the needs of this article among Polish students. The research aims to explore the set of issues related to the reasons for becoming interested in Facebook among students and it has shown its role in the information management-related processes. The final part presents conclusions to be drawn from the research in question as well as its limitations. The end of the article provides reflections concerning the causes and consequences of Facebook's growing significance in the Internet space.

\section{INFORMATION MANAGEMENT IN THE NETWORK SOCIETY}

Information, as any other primary notion, is difficult to define. The founder of cybernetics, Norbert Wiener simply stated: "Information is information, not matter or energy" (Gitt, 2002). However this notion is generally understood as: "news, a message, tidings, a communicated matter, a notification, communication, instruction, a notice, communicating about something, data" (Kopaliński, 1983, p. 188).

For many people information is a form of media communication which: "describes, provides an account of facts or state of affairs, refers thereto, thus enabling the reader, retrieving the outcome of the reporter's cognitive activity, to create a mental image of this fact. It is achieved by means of words fulfilling notification functions, and therefore constructing unambiguous semantic intentions" (Tetelowska, 1972, p. 46).

It can be seen that the understanding of the notion of "management" in relation to media and its fundamental product "information" is very diverse and for this reason it requires a precise definition of what should be really understood as "management." Before this is done, it would also be worth saying what "management" is not. It most definitely is neither "control" nor "exerting influence", nor "directing", and all the more so, not "manipulating."

According to Peter Drucker, the 21st century will be the century of information, since it will become the fundamental resource of this century (2000, p. 104105). The same scientist draws attention to the qualities of information different from the traditional resources. This means that the fundamental economic laws referring to information as a resource must be defined anew. Drucker provides the following example: "If I sell a thing, e.g. a book, this means that I no longer possess it. If I impart information to someone, I still possess it. In reality, the information gains in value since it is known to a larger number of people. With an increasing number of information recipients, its value is increasing" (ibidem, p. 27; retranslated from Polish by Maciej Czuchra). In the 
case of traditional resources it is precisely vice versa: the scarcer the resource, the higher its price.

From the point of view of deliberations in this article, it is assumed that managing information via new media is the total of activities performed by an individual with the view to constantly order, but also organise and control informative-communicative processes with the use of new media. This paper treats information - in keeping with what has been written before - as the basic media resource, being a subject of description by various scientific disciplines.

Thanks to media, the world has become a type of a network (Castells, 2003, pp. 11-12). Numerous researchers (cf. Drucker, Koźmiński) indicate knowledge as the primary resource, determining individuals' behaviour in networks: "the primary function of a network is the sharing of knowledge between individuals. And this function determines the changeable 'pulsating' shapes of the network. It also leads to disintegration of monolithic structures controlled from a single centre" (Koźmiński, p. 40).

The contemporary technicised world is heading towards an increase in the areas of social exclusion. It seems that each human at some stage of their life reaches their level of incompetence. This in turn leads us to a conclusion that the process of information management (more broadly speaking: knowledge) requires both individuals and organisations to become entities who have mastered the art of constant learning in order to counteract any and all forms of informational and technological exclusion. Constant supplementation of information as a primary resource of the 21st century is a conditio sine qua non for normal functioning in the information society. In this case, 'normal' should be understood as one which can consciously take advantage of information and tools used to receive and process it - in short - to manage information, including the information from social information services.

\section{FACEBOOK - THE MOST POPULAR SOCIAL INFORMATION SERVICE IN THE WORLD}

For several years Facebook has unchallengeably been the most popular social information network site among Internet users. The number of active users of the service is increasing with each year and it seems that, contrary to some statements, it is not just an effect of a passing fad. In 2015, more than 1.4 billion Internet users from all over the world used Facebook (Retrieved from: http:/ / www.statista.com/statistics/272014/global-social-networks-rankedby-number-of-users/; Access 24 December 2016). This means an increase by more than $10 \%$ in comparison with 2014 . Smartphone use of the service has also been recorded increasingly more often. In 2015 the number of people logging in to Facebook exclusively via mobile devices has increased twofold in relation to the preceding year. 
Facebook is included within the social network sites category. American researchers Nicole B. Ellison and Danah Boyd (2008) define this group as follows:

"We define social network sites as web-based services that allow individuals to

(1) construct a public or semi-public profile within a bounded system,

(2) articulate a list of other users with whom they share a connection, and

(3) view and traverse their list of connections and those made by others within the system. The nature and nomenclature of these connections may vary from site to site."

It must be noted that the above mentioned authors always use the term of social network sites. This subgroup of services, fitting within the class of social media, is sometimes labelled by researchers as: social networking sites (social networking services). The aforementioned terms are sometimes used interchangeably. Yet, there is a subtle, although a rather substantial difference between them. According to the research, social services reflect the existing social networks rather than generating new connections (Lampe, Ellison, \& Steinfield, 2008; Boyd, \& Ellison 2008). The focus group research described in this paper confirms this state of affairs as well. For this reason, while speaking of Facebook in this paper, we shall use the term of a social network site (SNS).

Facebook is a social network service equipped with multiple functions. Users may use it to publish their photos and communicate with other users (friends) via a chat/IM application. The service also offers the so-called wall, displaying on-current-basis-updated posts of other users or profiles promoting people, companies, or events (the so-called fan pages). This functionality allows for the aggregation of content. It displays only those posts which a given user wants to see (those in relation to which the user uses the "Like" option). Interestingly, Facebook communication occurs both directly (chat/ IM application) and indirectly - by mutual "liking" of users' posts.

\section{FACEBOOK IN LITERATURE}

The unceasing popularity of Mark Zuckerberg's service is extremely interesting. Despite the fact that at the moment of its creation there were already a number of similar services (e.g. MySpace, while in Poland - Nk.pl) with a sizeable following, within several years Facebook has entirely dominated the market of social network sites. Although it is a group of media characterized by high dynamics, the position of the service does not seem to be threatened in the smallest degree - the number of active users is constantly growing. Facebook's domination makes it an object of researchers' interest a lot more than other SNSs. Empirical research concerning the service in perfect majority revolves around such issues as: positive and negative consequences of Facebook use (Andreassen, \& Pallesen, 2013; Andreassen, Torsheim, Brunborg, \& Pallesen, 2012; Chang, 2008; Musiał, 2011), creating identity and image in the net (Car- 
penter, 2012), using Facebook for marketing purposes (Kaplan, \& Haenlein, 2010; Miotk, 2013; Grzegory, 2011), Facebook's impact on personal relations and sense of self-worth (De Meo, Ferrara., Fiumara, \& Provetti, 2014; Turkle, 2013; Skues, Williams, \& Wise, 2012; Satici, \& Uysal, 2015; Sheldon, 2008). Facebook is frequently examined from the point of view of the social influence theory or uses and gratification theory (Smock, Ellison, Lampe, \& Wohn, 2011; Cheung, Chiu, \& Lee, 2011). The majority of research related to this service is based on quantitative data while qualitative analyses are less frequent. The scientific discourse also devotes relatively little attention to critical analyses concerning Facebook, although in the popular discourse they tend to appear more and more frequently.

In their works multiple authors also refer to issues related to Facebook's enormous popularity. On the pages of "Perspective on Psychological Science," Robert E. Wilson, Samuel D. Gosling and Lindsay T. Graham (2012) presented a review of the state of research into the causes of Facebook use. The researchers analysed 412 scientific publications. In doing so, they distinguished two main types of motivation: external and internal. Within the external motivations they isolated: a pressure originating from the individual's environment which encourages one to engage in Facebook-related activities by providing a specific stimulus. As far as the internal motivations are concerned, the researchers noted that the literature definitely most often mentions the need to keep in touch with friends and acquaintances and sharing content with them as the main motivation. We read: "The most common internal motivation discussed in the literature was users' desire to keep in touch with friends. Expanding on these findings, researchers have explored the underlying influence of 'social capital,' which refers to the benefits received from relationships with other people. To understand the connections between social capital and Facebook relationships, researchers have distinguished between strong and weak ties among Facebook friends. A typical Facebook user will directly communicate with a small core group of friends by posting comments or messages, indicating strong ties, and then follow the majority of friends through passive means such as viewing the news feed and browsing, indicating weak ties. Research has shown that users are able to cultivate weak ties in an informal manner, and Facebook use may help maintain previous relationships and crystallize otherwise ephemeral relationships" (De Meo, Ferrara, Fiumara, Provetti, 2014).

In this paper we offer a look at Facebook from the perspective of managing information via new media. We think that Facebook and the form this service has taken on constitute an answer to social needs existing in society in relation to management of information-communication processes. Since the question of causes for the huge popularity of Facebook is not unambiguous and researchers do not see eye to eye in this respect, whereas the service is constantly evolving, an inspiration emerged to conduct a research allowing for the re-exploration of this issue. 


\section{FACEBOOOK AS AN ANSWER TO NEEDS RELATED TO INFORMATION MANAGEMENT IN EVERYDAY LIFE}

\section{Objectives and methods}

Two rounds of research in the form of focused group interviews were conducted. This method was selected with the view to gaining a better understanding of Facebook users' motivations related to their use of the service and obtaining a deeper insight into these issues. The research aimed to obtaining information regarding the main and most important reasons for Facebook use, as well as the role this service fulfils in respondents' daily life. Interview sample selection was deliberate. Both studies used students as respondents since according to statistical data (Diagnoza społeczna, 2015), young people and educational system participants in Poland face the least risk of digital exclusion and possess a relatively high level of competence. 11 respondents took part in Study 1. The study was carried out in an academic center in a small city (population of 120 thousand), whereas Study 2 was carried out in an academic center in a big city (population exceeding 750 thousand), and covered 8 participants. The course of the research was recorded and participation was voluntary. Respondents' age interval was 19-24.

The first study (hereinafter: Study 1) was carried out in April and the second (hereinafter: Study 2) in October 2015. In both cases, the interview scenario covered the most important issues related to Facebook use. Focus group participants answered similar questions in keeping with an earlier prepared scenario. The questions were related to:

- circumstances and reasons for creating a Facebook profile,

- use and role of the service in everyday life,

- Facebook's advantages and disadvantages observed by the respondents,

- observations regarding the functionalities available in the frames of the service.

The research was in-depth and, in connection with the method used (Silverman, 2009; Gawlik, 2012), not fully structured. The framework scenario of the research had been drawn up, however, in the course of interviews new, previously not foreseen issues would appear (e.g. respondents' dislike of the service being the subject of the research).

\section{Limitations}

The research is not representative, therefore the results and conclusions drawn from the studies may not be extrapolated onto the general population. After all, it was not the purpose of the research. On the other hand, though, they permit a look at the Facebook phenomenon from the point of view which has been hitherto underexposed in the literature of the subject: i.e. from the point of view of processes as well as needs of people living in the information society. Hence, the research highlights a need, while in fact a necessity for constant, coordinated, efficient and effective information management. Conclusions from the presented research do not provide an unambiguous answer to 
questions on the causes of Facebook's popularity, but only offer one of more possible hypotheses while, above all, they are to provide an inspiration for further in-depth analyses of this issue.

The fact that over the years Facebook has undergone substantial changes is also of relevance. First and foremost - the number of its users as well as the formula of its functioning have been subject to change. That which today attracts Internet users to this service may significantly differ from the motives of Internet users creating their Facebook accounts ten years ago. Therefore, updating the state of knowledge on the scope of causes for an unceasing popularity of the service on current basis seems to be desirable.

\section{Data analysis and results}

Both in Study 1 and Study 2, participants mentioned differing reasons which induced them to create their Facebook accounts. The group of respondents included both people who activated their accounts relatively recently and those with several-years-old profiles. In both groups the need to have access to information obtained via Facebook is clearly visible. Research excerpt 1 presents fragments of participants' statements:

Research excerpt 1:

Statements of participants concerning their reasons for creating a Facebook account (Study 1)

Student 1: When I went to high school, a classmate set up a Facebook group, a group for our grade. Initially, very few people joined, maybe a half of all the people, but when the others noticed how much information there is, that we post many class photos, they decided they also wanted to participate in it and set up their own accounts.

Student 1: I resisted Facebook for a long time (...), but I gave in to the group pressure. It was in high school. There was plenty of information on Facebook, information on our grade, notes, tests, so I decided to set up (an account), though I resisted (it) for a long time. They were trying to convince me for a very long time ...

Moderator: And what arguments did they use when they were trying to convince you?

Student 1: That a lot is going on there, that there's a lot of information exchange going on, e.g. event information that I don't know about anything, that I don't go anywhere...

Moderator: And was it true?

Student 1: In a way, yes ... When I set up the Facebook account I began going out more ...

(...)

Student 2: In my case it was more (...) that I just wanted to check what this Facebook was all about because all my mates were enthralled, they kept saying what a great site Facebook is. Later, I got into it myself a bit, but these days I am considering deleting my account more and more seriously (...), I do not use it as willingly as before.

Student 2: With me it was like with the others. Kind of a lemming-rush (...), everybody was setting up their accounts, I was wondering why this is so ...

(...) 
Student 3: I set up my Facebook to play, (...) but I do not play anymore, well, I won't be removing the account now as there really is a lot of information and you can find out a lot from Facebook, so I am not going to delete the account, but my activity there is virtually nil.

(...)

Student 3: Once I saw in the Internet that there's this thing called Facebook and, you know, I wanted to see what it was. So I did, I didn't get it at all and for a year or so I never used it. (...) Then, my mates started using Facebook, and so did I and I finally got what it was all about...

Student 4: In my case it was the same as with my mates. It began to feature in conversations, I got interested in it a little (...). I mainly treat it as a source of information, what is going on in the world, what is happening in subjects I am interested in, I "liked" some profiles and all this just pops on my "wall." It's probably also in a way due to my laziness, but it's simply convenient and this is the main reason. Not so much to see what my mates are up to, although that too, obviously ... Mainly to know what is going on in the world, in sports, music, politics (...). If I didn't have it I'd probably be visiting all these internet sites, but here it's all in one in reality and it's a lot more convenient.(...)

(Source: Author's research).

The material presented above demonstrates that although direct reasons for creating a Facebook account are highly diversified, in time the issue of information management becomes the most prominent. The same seems to be true in Study 2. Research excerpt no. 2 contains fragments of statements made by participants of the second study related to the reasons for setting up a Facebook profile:

\section{Research excerpt 2:}

Statements of participants concerning their reasons for creating a Facebook account

(Study 2)

Student 1: During holidays we decided to set up a Facebook group for our course, and so this was also the reason for me to set up a Facebook account. (...) Earlier, doing other courses, I'd also have one, precisely for the same reason.

(...)

Student 2: I've been on Facebook for two months and I created the account also only to be able to get in touch with people about university matters.

Student 3: I had already had an account (...) at first, I didn't really know how to use it, I played games, and then I made some friends and an information exchange began, and some events started to pop up, so it's sort of a place that maybe puts some order in my life.(...)

Student 4: I created (the account) when it was becoming trendy. At first, I used it to keep track on my mates, also those you don't really know, but you'd like to find out something about, and now - it's purely for information (...), now it's mainly about the course-related information, about events, this type of things ... 
Student 5: (...) I don't know why I created my account, everybody else was doing that and so did I. Now, I just realized it's not necessary ... I mean it is necessary if you are in college and you want to get organized, but personally I prefer texting my friends a lot more, or just meeting with them since I am sort of fed up with all this Facebook (...).

Student 6: (...) I created my account out of curiosity, I did it because others were doing it too.

Student 7: My mates talked me into it because everybody else was using it (...). Well, now (...) simply all the information is there, everybody is writing if anything is going on, not every day you have time to check, for example, your two email accounts and all the websites, while on Facebook all the news is simply in one place, and so it's helpful, but I am trying to limit my use, e.g. I just devote 15 minutes to check it for something of importance cause, I don't know .... Personally, I don't really like Facebook, but since it is so useful, you have to check it. For example, cultural events are announced when you like one page, similar offers turn up (...).

Student 8: I set up my account two years ago when I was on an international exchange (...). I had to keep in touch with friends from different European countries (...).

(Source: Author's research).

The first respondent states that she set up her Facebook account to be able to keep in touch with other users. However, the further part of her statement demonstrates that these contacts are not aimed at maintaining relationships, but at gaining access to information about university life. The respondents declare various reasons for creating a Facebook account, nevertheless, the majority of them above draw attention to its significant role as, first and foremost, a guarantee of access to information. Similarly as in Study 1, a dislike for Facebook is visible, at times it is expressed directly. The majority of respondents in both Studies strongly emphasize the need to use the service in connection with the necessity to be up-to-date with information that is important from their point of view. The issue of maintaining or establishing interpersonal relationships recedes into the background. Even if the contact with other users is established then it is frequently done in order to obtain specific information. In turn, if other users' profiles are visited, it is done not to start a conversation with them, but rather to find out something about them.

Certain differences can also be detected between people who have set up their accounts recently and those who have had their accounts for a longer period of time (several years). The former mainly point to the needs related to having access to information on a current basis, while the latter as a direct reason (for having an account) quote other issues, yet they note that in time Facebook has first and foremost become a tool for efficient and effective information management.

Respondents participating in both Studies express an explicit and strong need for security in terms of access to information. This confirms the thesis of its enormous contemporary value (Nierenberg, 2011). The access must be available on a running basis, most preferably permanently, but it also must be 
safe (the respondents must be sure that information is verified and up-to-date). The need for security in terms of access to information in the context of Facebook is more significant than the need to keep in contact with other users and friends. None of the respondents mentioned that the service allowed them to establish new relationships and acquaintanceships. In turn, one of the students emphasized that as far as contacts with her friends were concerned, she definitely preferred to contact them in person or by phone.

The respondents very often stressed that for them Facebook constituted a certain type of universal and multifunctional tool. Research excerpt no. 3 contains statements made by participants of Study 1 in relation to this thread:

\section{Research excerpt 3}

Respondents' statements regarding Facebook as an information management tool

(Study 1)

Student 1: I never thought Facebook would become so popular. I resisted creating an account for a long time, a high school mate talked me into it and I think it was a good idea (...). In time I've stopped using other services and communicators. Presently Facebook is the only tool I use and there's no way I am giving up on it (...). I don't have Instagram or Snapchat accounts, and Facebook is enough for me as a tool of information, reading news, and communicating with others (...). I use it several times a day, now I am also checking it (...). I think you need to have at least this one tool, and Facebook has become just such a tool ...

Student 1: I created my account right before going to college. I kind of suspected that it was going to come in handy, and I was right. There are days when something new appears literally every twenty minutes, and then I am really fed up with all this Facebook... Anyway, I am not thinking of deleting my account yet, I am going to keep it for a while, it must be like that for the time being.

Student 3: As far as a test of a kind goes, whether I can live a week or two without Facebook, I think I could easily deactivate the account (...) sure I could but, just like everyone else here has said, it's such a cool tool for everything: for communicating and finding out what your mates are up to, and precisely for collecting the knowledge about everything you are interested in, that is I pick pages which somehow fit into the area of my interests and I click if I want to get notifications related to this or other thing, I go to my "wall" and I've got all I need, it seems to me it is so... well... useful. I log in and there it is - all in one.

(...)

I have all the information in one place, if there was no Facebook, all this info could also be accessed, I'd just directly visit all the services which I browse via Facebook, but it's a lot cooler to have it all in one place, since otherwise it takes so much more time.

Student 1: All this information can be accessed in the Internet, you can use communicators, admittedly, it's not all in one anymore, but you can access it (...). Yet, we are striving to optimize everything, in all areas of life in fact.

Student 1: It's just convenient if you don't feel like searching, you have it all in one place (...). 
Student 3: The main thing is the speed, of course! You're on a train or bus, you just go to your Facebook and you have it all, and you have time to view all the news from the recent hours, while if we were to go to each individual website, it would take a lot more time, moreover, it would use up more data transfer ... Opening 8 websites and opening one Facebook - that is a difference!

(...)

Student 4: (...) I find it to be far too addictive, and a while ago I resolved that after getting my degree, because right now I still need it - if someone posts something on Facebook I have to have access to this information, for example classes have been cancelled or something, but after leaving college, I'd like to delete this Facebook, not to have it any more, since it is so horribly addictive.

(Source: Author's research).

Based on the statements from research excerpt no. 3, it is possible to conclude that in the process of obtaining information, the following aspects are of particular importance: access speed (the less time required the better), effort and outlays required to own it (the number of actions to be performed - the fewer the better; the cost - the lowest cost being preferable, it is best to obtain information free-of-charge). Participants of Study 2 offered similar comments:

Research excerpt 4

Respondents' statements regarding Facebook as an information management tool

Study 2

Student 2: Facebook reminds me about many, many things, for example about various events, or even my mates' birthdays. (...)

Student 3: Messenger in any case makes things a lot easier, it's simpler than text messages, there used to be Gadu-Gadu, but nobody uses it anymore, now the Messenger is all there is for a direct conversation (...).

Student 5: I do not use Messenger, for example, I got really wound up that, for example, so many people were writing to me, the whole crowd, I just don't like it, I prefer to decide myself when to write someone back, or how many people I'll speak to. When I am sending a text, no-one sees whether I am available or not (...), yet as a form of an organizer, Facebook is a great idea. For example, if I don't visit it for a couple of days, I later do not know what is going on, for example, I don't know that some classes have been cancelled, that something has happened, someone found out there were no more tickets for some event, that there's some event, and then I am left behind and big time on top of that ... (...).

Moderator: Can't such information be obtained in some other way?

Student 1: There are other possibilities and you can just jump from website to website and collect it all, but it's somehow ... Let's say that in each organized group there are these three people who like finding information and share it and I kind of thrive on this and on these people (laughing). This is what I need Facebook for, I am a lazy person, and Facebook helps very much in this respect (...).

(Source: Author's research) 
The enormous wealth of information available in the Internet renders personalization of Internet content extremely desirable, because this way we receive only the content of interest to us. We do not have to waste time searching, we screen the unnecessary data, we can be almost certain that whatever we are looking for, sooner or later will be offered to us. Facebook meets these needs perfectly. The solutions introduced by the service, such as for example the messenger mentioned by one of the respondents, are gradually replacing alternative solutions. It is therefore visible that students are aiming to minimize the number of communication-information tools they use. Facebook is a universal tool, allowing one to manage more than one aspect, and for this reason in time it becomes the only service used by its users.

Students also frequently pointed to consequences of delay in access to information. Research excerpt no. 5 contains statements of respondents related to this issue:

\section{Research excerpt 5}

Statements on delays in access to information

Study 1

Student 1: In our group the "first come, first served" is frequently the case, for example with signing up for groups. A delay in accessing information may be detrimental. You are too late, you miss out on opportunities. It shows the nonsensical nature of it all, sometimes literally 7 minutes after the post is published it's all sorted. You need to be on Facebook practically all the time.

(...)

Student 2: There's information about date changes, e.g. exam dates (...). If you don't manage to get some information on time, well, that's unfortunately your problem. (Source: Author's research).

As can be seen, a failure to obtain important information on time may engender negative consequences, including a loss of opportunities and, therefore, also access to e.g. material resources. This is why monitoring information sources is becoming a necessity. Facebook is very helpful in this regard since it guarantees a sense of full security and of being up-to-date. Moreover, it is multifunctional. This is why nowadays, in the era of widespread availability of devices with mobile Internet access, asking students how much time they spend on Facebook seems to be devoid of grounds, whereas postulates on limiting youths' access to this service appear outright bizarre.

\section{DISCUSSION AND CONCLUSION}

The conducted research revealed three main research categories related to Facebook use:

(1) A need for security in the scope of access to information,

(2) Needs related to information-communication processes management, and the third, rather surprising: 
(3) Facebook users' dislike for the service itself and for its "omnipresence."

Analysing the material from both Studies, one may arrive at a conclusion that for the respondents Facebook constitutes the fundamental and only channel of information. The service is used not only to obtain information, but to manage a number of aspects related to the day-to-day functioning: it aggregates content, reminds about important events, allows one to monitor other users' content on a current basis, allows one to communicate with others without time-and-space limitations. These issues came to the foreground in both Studies, whereas the issues related to maintaining relationships with other users were of secondary importance. The respondents seldom indicated that Facebook provides them with entertainment or is a preferable form of a leisure activity. The conclusions to be drawn from the research described in this paper correspond with the results of other analyses related to Facebook's role in obtaining and proliferating information and content (Kümpel, Karnovski, \& Keyling 2015; Popiołek 2015).

However, the dislike for the service, frequently declared by the respondents, seems to be particularly interesting. The respondents delivered their statements in a manner suggesting that their Facebook use is more of a necessity than free choice. There were voices pointing to being tired of the website. Many people declared that they would gladly resign from using Facebook, but they considered it to be too risky.

Looking at the site the way the respondents view it - as a tool used for efficient and effective management of a number of information-communication processes - one may easily conclude that it is extremely useful, not to say indispensable. The problem appears when we realize that it is not a neutral tool. It is a private enterprise daily collecting and processing enormous amounts of data on each user. Facebook is an organization whose primary objective is not the good and satisfaction of its users, but rather its own survival and development. It is thanks to the permanent presence and trust of wide swathes of Internet users that the corporation is maximizing its profits (Kreft 2015). On top of that Facebook is tracking every movement of every user, 24/7, and the data thus obtained is frequently sold to other companies for marketing purposes. Therefore, the user - Facebook transaction is of an exchangeable nature: convinced that they have gained a free tool, everyday Internet users pay a huge price. However truly frightening is the fact that Facebook-using Internet users feel that they cannot stop using it even if they wanted to.

\section{REFERENCES}

1. Andreassen, C. S., \& Pallesen, S. (2013). Facebook addiction: A reply to Griffiths (2012), Psychological Reports, 113(3), 899-902.

2. Andreassen, C. S., Torsheim, T., Brunborg, G. S., \& Pallesen, S. (2012). Development of a Facebook addiction scale. Psychological Reports, 110, 1-17.

3. Boyd, D., Ellison, N. B. (2008). Social Network Sites: Definition, History, and Scholarship, Journal of Computer-Mediated Communication 13(1), 210-230. 
4. Carpenter, C. J. (2012). Narcissism on Facebook: Self-promotional and anti-social behavior, Personality and Individual Differences, 52(4), 482-486.

5. Castells, M. (2003). Galaktyka Internetu [Internet Galaxy]. Poznań: Dom Wydawniczy Rebis.

6. Chang, M. K., \& Law, S. P. M. (2008). Factor structure for Young's addiction test: A confirmatory study, Computers in Human Behavior 24(6), 2597-2619.

7. Czapiński J., \& Panek T. (Eds.). (2015). Report: Diagnoza społeczna 2015 [Social Diagnosis 2015]. Warszawa: Rada Monitoringu Społecznego.

8. Czechowicz, B. (2015). Facebook ma już prawie 1,4 mld aktywnych użytkowników [Facebook has almost 1.4 billion active users]. Retrieved February 1, 2015, from: http:/ / pclab.pl/news61762. html.

9. De Meo, P., Ferrara E., Fiumara, G., \& Provetti, A. (2014). On Facebook, most ties are weak. Communications of the ACM, 57(11), 78-84.

10. Drucker, P. (2000). Zarzadzanie w XXI wieku [Management in the 21st century]. Warszawa: Muza.

11. Gawlik, K. (2012). Badania fokusowe [Focus Group Interwiev]. In: D. Jemielniak (Ed.) Badania jakościowe. Metody i narzędzia [Quantitave research methods] (pp. 131-163). Warszawa: PWN.

12. Gitt, W. (2002). Am Anfang war die Information. At the beginning there was an information) Hänssler Verlag, Holzgerlingen; Retrieved Fenruary 1, 2015, from: http://chfpn.pl/ files/?id_plik=393.

13. Grzegory, M. (2011). Serwisy społecznościowe jako narzędzie marketingowe [Social network sites as an marketing tool]. Zeszyty Naukowe Uniwersytetu Szczecińskiego, 656(28), 35-47.

14. Kaplan, A. M., Haenlein, M. (2010). Users of the world, unite! The challenges and opportunities of social media. Business Horizons 53(1), 59-68.

15. Kopaliński, W. (1983). Stownik wyrazów obcych i zwrotów obcojęzycznych [The Dictionary of foreign words]. Warszawa: Wiedza Powszechna.

16. Koźmiński, A. K. (2004). Zarzadzanie w czasach niepewności [Management in times of uncertainty]. Warszawa: Wyd. Naukowe PWN.

17. Kreft, J. (2015). Za fasada społeczności [Behind the community façade]. Kraków: Wyd. UJ.

18. Kümpel, A. S, Karnovski, V., \& Keyling, T. (2015). News Sharing in Social Media: A Review of Current Research on News Sharing Users, Content, and Networks, Social media + society, 1(2), 1-14.

19. Lampe, C., Ellison, N., \& Steinfield, C. (2008). Changes in use and perception of Facebook. [In:] Proceedenigs of the 2008 conference on computer-supported cooperative work. Retrieved Fenruary 1, 2015, from: https://www.msu.edu/ nellison/LampeEllisonSteinfield2008.pdf.

20. Miotk, A. (2013). Skuteczne social media [Effective social media]. Gliwice: Helion.

21. Musiał, J. (2011). Rozwój serwisów społecznościowych i ich wpływ na teraźniejszego obywatela internetowego [Development of social network sites and its impact on internet citizens]. Zeszyty Naukowe Uniwersytetu Szczecińskiego: Studia Informatica, 28, 311-319.

22. Popiołek, M. (2015). The role of Facebook in the process of acquiring information. Own research study. Journal of Education, Culture and society, 1(2015), 75-85.

23. Satici, S. A., Uysal, R. (2015). Well-being and problematic Facebook use. Computers in Human Behavior, 49(2015), 185-190.

24. Sheldon, P. (2008). The relationship between unwillingness-to-communicate and students Facebook use. Journal of Media Psychology: Theories, Methods, and Applications, 20(2), 67 - 75.

25. Silverman, D. (2009). Podstawy badań społecznych [Social science research]. Warszawa: PWN.

26. Skues, J. L., Williams, B., \& Wise, L. (2012). The effects of personality traits, self-esteem, loneliness, and narcissism on Facebook use among university students, Computers in Human Behavior, 28(6), 2414-2419.

27. Smock, A. D., Ellison, N. B., Lampe, C., Wohn, D. Y. (2011). Facebook as a Toolkit: A Uses and Gratification Approach to Unbundling Feature Use. Computers in Human Behavior, 27(6), 2322-2329.

28. Tetelowska, I. (1972). Informacja - odrębny gatunek dziennikarski [Information - a distinct journalistic genre]. In: P. Dubiel, W. Pisarek (Eds.), Szkice prasoznawcze (Media lineament), Kraków: Wyd. Uniwersytetu Jagiellońskiego.

29. Turkle, S. (2013). Samotni razem [Together alone]. Kraków: Wyd. Uniwersytetu Jagiellońskiego.

30. Wilson, R. E, Gosling, S. D., Graham, L. T. (2012). A review of Facebook research in the social sciences. Perspective on Psychological Science, 7(3), 203-220. 